\title{
Evaluation of barrier functions of traditional water supply facilities in relation to toxic trihalomethanes
}

\author{
Zhanna Govorova $^{1, *}$, Galina Gorenko ${ }^{2}$, Uliana Rudich $^{1}$ and Vadim Govorov ${ }^{1}$ \\ ${ }^{1}$ Moscow State University of Civil Engineering, Yaroslavskoe shosse, 26, Moscow, 129337, Russia \\ ${ }^{2}$ MGIMO University (Moscow State Institute of International Relations), Department of Spanish, 76, \\ av.Vernadskogo, 119454 Moscow, Russia
}

\begin{abstract}
The problem of formation of the toxic carcinogenic substances in the process of the water treatment during disinfection of natural waters containing organic pollution is actual both in Russia and in foreign countries. There is an information about the negative effects of trihalomethanes (THM) on the human organism. The examples shows that, the concentration of trihalomethanes in the drinking water exceeds the standards several times in water treatment according to the traditional technology with the use of chlorine. The aim of the work was to study the dynamics of THM changes in the stages of purification in the comparison with the water quality, the reagent treatment modes and technological parameters to assess the barrier role of existing water supply stations. It was found that the standard degree of the purification achieves with chromaticity, turbidity, permanganate oxidation, bacteriological parameters. At the same time, the prechlorination of water with a temperature of $1{ }^{\circ} \mathrm{C}$ and a chromaticity of $67-71{ }^{\circ} \mathrm{C}$ leads to the formation of chloroform in the amount of 40-61 $\mu \mathrm{g} / \mathrm{l}$, and postchlorination at the final stage of the full cycle contributes to an increase in the concentration to 192-215 $\mu \mathrm{g} / \mathrm{l}$. The new data were the basis for the development of the improved water purification technology and measures for the modernization of the water supply stations.
\end{abstract}

\section{Introduction}

The problem of formation of the toxic substances connected not only with the pollution of the source of the water supply with organic and mineral impurities, but also with the transformation of the chemicals in the process of its purification. The inclusion of an important stage disinfection using chlorine-containing reagents in the process of the water preparation leads to the formation of the toxic carcinogenic products (trihalomethane (THMs), halogenated and ketones, haloacetonitriles, haloacetic acid and others). The toxicological harmful basis is installed for all carcinogens. The most dangerous substances formed in the drinking water during chlorination are trihalomethanes [1-2] (Table 1).

\footnotetext{
*Corresponding author: GovorovaZhM@mgsu.ru
} 
There are strict requirements regulated by the relevant regulations in force in Russia, the United States, the EU (European Union), so on, the content of trihalomethanes in drinking water (Table 2).

Table 1. Toxicity of trihalomethanes.

\begin{tabular}{|c|c|c|}
\hline Trihalomethanes & Class & Negative effect \\
\hline Chloroform & B2 (probable carcinogen) & $\begin{array}{c}\text { Cancer, liver, kidneys, negative } \\
\text { impact on the reproductive system }\end{array}$ \\
\hline Chlorodibromomethane & C (possible carcinogen) & $\begin{array}{c}\text { Nervous system, liver, kidneys, } \\
\text { negative impact on the reproductive } \\
\text { system }\end{array}$ \\
\hline Bromodichloromethane & B2 (probable carcinogen) & $\begin{array}{c}\text { Cancer, liver, kidneys, negative } \\
\text { impact on the reproductive system }\end{array}$ \\
\hline Tribromomethane & B2 (probable carcinogen) & $\begin{array}{c}\text { Cancer, nervous system, liver, } \\
\text { negative impact on the kidneys }\end{array}$ \\
\hline
\end{tabular}

Table 2. Normative requirements for concentrations of trihalomethanes in drinking water $(\mu \mathrm{g} / \mathrm{l})$.

\begin{tabular}{|c|c|c|c|c|c|c|c|}
\hline Trihalomethanes & 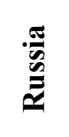 & $\stackrel{0}{\stackrel{0}{1}}$ & 岕 & $\begin{array}{l}\text { हैं } \\
\text { के }\end{array}$ & Uัँ & 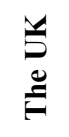 & 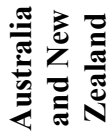 \\
\hline Chloroform & 60 & 200 & \multirow{4}{*}{$\begin{array}{c}80 \\
(40)\end{array}$} & \multirow{4}{*}{100} & \multirow{4}{*}{100} & \multirow{4}{*}{100} & \multirow{4}{*}{250} \\
\hline Chlorodibromomethane & 30 & 100 & & & & & \\
\hline Bromodichloromethane & 30 & 60 & & & & & \\
\hline Tribromomethane & 100 & 100 & & & & & \\
\hline
\end{tabular}

The formation of the trihalomethanes depends from many factors [3-10]. These are the content of organic and inorganic (e.g., bromides, ions of some metals, etc.) substances in the natural water, water temperature (T), $\mathrm{pH}$, chlorine dose (D) and the duration of water contact with chlorine $(\mathrm{t})$. With an increase in $\mathrm{pH}$ from 7 to 9 , the concentration of THMs increases 2-3 times, the temperature increase by $10{ }^{\circ} \mathrm{C}$ leads to an increase in the concentration of chloroform twice, with the chlorination of humic acids, the concentration of the chloroform by $40 \%$ more than fulvic acids. The maximum amount of chloroform formed at a contact time of $8 \mathrm{~h}[4,6]$.

There is the data on concentrations of the chloroform and trihalomethanes in drinking water at the outlet of the water treatment plants before entering the distribution network in table 3 and table 4 [4-5, 11-12].

Water treatment at the stations was carried out according to the traditional technology. Chlorine $\left(\mathrm{Cl}_{2}\right)$ was used in the most cases to oxidize impurities and disinfect water. The concentrations of chloroform formed in the drinking water are much higher than the standards. The inclusion in the technological scheme of the use of powdery activated carbon (PAC) or the use of another chlorine oxidant instead of chlorine, for example, potassium permanganate $\left(\mathrm{KMnO}_{4}\right)$ and sodium hypochlorite $(\mathrm{NaOCl})$, reduces, but does not exclude the formation THMs in the water treatment process (Table 4). 
Table 3. Concentration of chloroform.

\begin{tabular}{|c|c|c|}
\hline River (Russia) & Water treatment technology & Chloroform, $\boldsymbol{\mu g} / \mathbf{l}$ \\
\cline { 1 - 1 } The Volga & & 71.8 \\
\cline { 1 - 1 } The Oka & \multirow{2}{*}{$\begin{array}{c}\left.\text { Oxidation }\left(\mathrm{Cl}_{2}\right) \rightarrow \text { coagulation(flocculation }\right) \rightarrow \\
\text { sedimentation } \rightarrow \text { filtration } \rightarrow \text { disinfection }\left(\mathrm{Cl}_{2}\right)\end{array}$} & 308.2 \\
\cline { 1 - 1 } The Don & & 75.1 \\
\cline { 1 - 1 } The Kama & & 161.3 \\
\hline
\end{tabular}

Table 4. The concentration of trihalomethanes in the drinking water.

\begin{tabular}{|c|c|c|}
\hline $\begin{array}{l}\text { Location of the } \\
\text { waterworks / water } \\
\text { source }\end{array}$ & Water treatment technology & $\begin{array}{c}\text { THM, } \\
\mu \mathrm{g} / \mathrm{l}\end{array}$ \\
\hline $\begin{array}{l}\text { Spain (province of } \\
\text { Córdoba) / reservoir } \\
\text { (Sierra Boyera) }\end{array}$ & $\begin{array}{l}\text { Oxidation }\left(\mathrm{Cl}_{2}\right) \rightarrow \text { coagulation(flocculation) } \rightarrow \\
\text { sedimentation } \rightarrow \text { filtration } \rightarrow \text { disinfection }\left(\mathrm{Cl}_{2}\right)\end{array}$ & $100-150$ \\
\hline $\begin{array}{l}\text { Spain (province of } \\
\text { Huelva) / reservoir } \\
\text { (Chanza, Canal del } \\
\text { Piedras) }\end{array}$ & $\begin{array}{l}\text { Oxidation }\left(\mathrm{KMnO}_{4}\right) \rightarrow \text { coagulation } \rightarrow \text { flocculation } \rightarrow \\
\text { sedimentation } \rightarrow \text { filtration } \rightarrow \text { disinfection }(\mathrm{NaClO})\end{array}$ & 26.4-32.9 \\
\hline $\begin{array}{l}\text { Columbia }(\mathrm{Cali}) / \\
\text { river (Cauca) }\end{array}$ & $\begin{array}{l}\text { Adsorption }(\mathrm{PAC}) \rightarrow \text { oxidation }\left(\mathrm{Cl}_{2}\right) \rightarrow \text { coagulation } \\
\quad \text { (flocculation) } \rightarrow \text { sedimentation } \rightarrow \text { filtration } \rightarrow \\
\text { disinfection }\left(\mathrm{Cl}_{2}\right) \rightarrow \mathrm{pH} \text { correction }\end{array}$ & 12.9 \\
\hline $\begin{array}{l}\text { Irak (Bagdad)/ } \\
\text { river (Tigris) }\end{array}$ & $\begin{array}{l}\text { Oxidation }\left(\mathrm{Cl}_{2}\right) \rightarrow \text { coagulation(flocculation) } \rightarrow \\
\text { sedimentation } \rightarrow \text { filtration } \rightarrow \text { disinfection }(\mathrm{NaClO})\end{array}$ & 41.6 \\
\hline
\end{tabular}

For the prediction of THMs formation were obtained mathematical model by various authors [4-6]. The calculated concentration of chloroform $(C)$, formed in the process of the water treatment, can be tentatively determined by the formula [4] (1).

$$
C=55.1+1.33 C O D(p H-6.75)+(3.39 C O D+25.8) /\left(1+20 \mathrm{e}^{-0,4 D}\right)+40.3 \ln (1+t)-12,7 p H
$$

Formula (1) can be used at $p H 5-9$, chemical oxygen demand (COD) 15-75 mg/l, D = 3$12 \mathrm{mg} / \mathrm{l}, t=1.5-15 \mathrm{~h}$.

The authors of [5] developed a mathematical model that allows to predict the concentration of THMs in the distribution network depending on the temperature $(T)$, total organic carbon (TOC), $\mathrm{pH}$, chlorine dose $(D)$ and the adopted water treatment technology.

$$
\log \text { THMs }=-4.42+3.72 \log (T)+1.04 \log (p H)-0.042 \log (\text { TOC })+0.211 \log (D)
$$

However, in each case, the number of formed THMs, its transformation in the process of water treatment and distribution network will be individual depending on the degree of contamination of the water supply source, the local conditions, adopted technology and treatment modes.

In order to improve the protective functions of the water supply facilities, substantiate and development the new improved technology, determine the parameters of the water supply facilities and development of the measures for reconstruction and modernization, it is necessary to study the dynamics of the formation and changes in the concentrations of THMs in the water by stages of purification in the comparison with the doses of regents and technological parameters in real time. 


\section{Materials and methods}

The work of two stations, which were built in the 60-80s of the last century, was analyzed. There were different reagent technologies for the water purification were at the stations. The chlorine was used for the disinfection.

The sampling of the water samples for analysis performed from the river, after the mixer, the flocculation chamber and a sump or clarifier with a layer of suspended sediment, the filter, the tank for purified water, the pumping station before the supply of the drinking water to the distribution network. The sampling of the water carried out at the intervals, taking into account the actual time of the water stay in the constructions.

The water quality was estimated by indicators of the turbidity, chromaticity, permanganate oxidation, the residual chlorine and the others with using standard methods (state standards: GOST R 57164-2016, GOST 31868-2012, GOST R 55684-2013, GOST 18190-72) and the certified equipment. The volatile halogenated hydrocarbons (bromodichloromethane, bromoform, dibromochloromethane, tetrachlorethylene, trichlorethylene, chloroform, carbon tetrachloride) in the water were determined by a certified method based on a vapor-phase gas chromatographic analysis [13].

\section{Results}

There were research in the winter. This period characterized by low temperatures of river water, the minimal bacterial contamination of the water source and the concentration of organic contaminants.

The river is the source of the water supply. The water temperature did not exceed $1{ }^{\circ} \mathrm{C}$, during the test period an earthy smell with an intensity of 1-2 points dominated. The water was characterized by the chromaticity of 66-71 degrees and the slight turbidity (4.9-5.29 $\mathrm{mg} / \mathrm{l}$ ), the permanganate oxidizability was $11-12 \mathrm{mgO}_{2} / 1$, the water $\mathrm{pH}$ was $7.85-7.87$, the alkalinity did not exceed $3.7 \mathrm{mmol} / \mathrm{dm}^{3}$. The total microbial number did not exceed 80 $\mathrm{cfu} / \mathrm{ml}$, coliform organisms and thermotolerant coliform organisms, respectively - 191.5 and $178.5 \mathrm{cfu} / 100 \mathrm{ml}$. In addition, the coliphages attended in an amount of 20 to $28 \mathrm{pfu} / \mathrm{ml}$ in the river water.

At the station №1, a two-stage water purification technology including the prechlorination and postchlorination, the coagulation followed by clarification and bleaching of the water in horizontal sedimentation sumps and the filtration of high-rate filters were designed. At the station, №2 provides the prechlorination and postchlorination, reagent purification of the water in the clarifiers with a layer of suspended sediment, equipped with recirculators and high-rate filters.

The aluminum sulfate coagulant with a dose of $45 \mathrm{mg} / \mathrm{l}$ in $\mathrm{Al}_{2}\left(\mathrm{SO}_{4}\right)_{3}$, flocculant polyacrylamide with a dose of $0.3 \mathrm{mg} / \mathrm{l}$ were used at the stations. The coagulant solution was dosed into the pipeline before of the mixer, the flocculant solution was dosed into the last chamber of the mixer. The prechlorination of the water was provided in two stages: to the pipeline of river water before the mixer and the clarified water line before the filters, and postchlorination to disinfect the purified water into the filtered water pipeline. The doses of chlorine were prescribed with the condition of the content of the residual chlorine that is $0.8-1.2 \mathrm{mg} / \mathrm{l}$ in the drinking water. The filtration rate was 2.3 to $5.1 \mathrm{~m} / \mathrm{h}$.

The results of the research are presented in Table 5 and in Fig. 1 and Fig. 2. Table 5 shows the values of the indicators in the treated water after the every construction. An analysis of the observational data showed that the drinking water met the requirements of the standards [14] for physicochemical and bacteriological indicators with accepted regimens of reagent treatment, regardless of technology. The exception is the indicator of THMs. 
Table 5. Change in water quality indicators for purification stages.

\begin{tabular}{|c|c|c|c|c|c|c|c|c|}
\hline \multirow{2}{*}{ Sampling points } & \multicolumn{7}{|c|}{ Indicators } \\
\cline { 2 - 10 } & \multicolumn{2}{|c|}{ Turbidity, mg/1 } & \multicolumn{2}{c|}{ Chromaticity, ${ }^{\circ}$} & $\begin{array}{c}\text { Permanganate } \\
\text { oxidizability, } \\
\text { mgO } / 1\end{array}$ & \multicolumn{2}{c|}{$\begin{array}{c}\text { Residual } \\
\text { chlorine, mg/1 }\end{array}$} \\
\hline Waterworks & No. 1 & No. 2 & No. 1 & No. 2 & No. 1 & No. 2 & No. 1 & No. 2 \\
\hline Source water & 4.9 & 5.0 & 69 & 66 & 12 & 12 & - & - \\
\hline After the precloration & 31.3 & 23.4 & 20 & 20 & 10 & 13 & 0.34 & 1.4 \\
\hline $\begin{array}{c}\text { Sedimentation Sump } \\
\text { Clarifier with a layer } \\
\text { of suspended sediment }\end{array}$ & 13.4 & - & 14 & - & 7.1 & - & 0.63 & - \\
\hline \begin{tabular}{c} 
Filter \\
\hline
\end{tabular} & 0.1 & 10.8 & 11 & 13 & 3.8 & 4.4 & 1.2 & 0.41 \\
\hline After the postcloration & 0.39 & 0.59 & 9 & 10 & 3.8 & 4.3 & 1.3 & 0.84 \\
\hline $\begin{array}{c}\text { Second pumping } \\
\text { station }\end{array}$ & 0.69 & 1.18 & 11 & 10 & 3.8 & 4.5 & 1.2 & 1.05 \\
\hline
\end{tabular}

Fig. 1 and Fig. 2 after shows that. The formation of chloroform in the amount of 40-61 $\mu \mathrm{g} / 1$ is after prechlorination, then, there is a slight decrease $(22-27 \%)$ in its concentration in clarified water after the sump and clarifier. In the filtrate, the concentration of chloroform increases again, due to the addition of chlorine before the filters and then there is an increase to $192-215 \mu \mathrm{g} / \mathrm{l}$ of the concentration of chloroform.

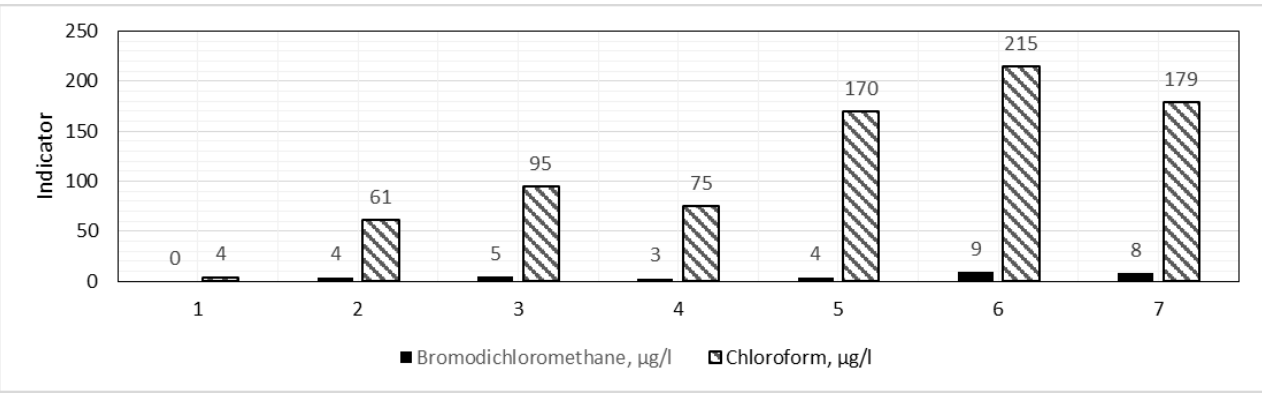

Fig. 1. Dynamics of change of trihalomethanes in the process of water purification at the waterworks № 11 - source water; 2 - after prechlorination; 3 - reaction chamber; 4 - sump; 5 - filter; 6 - tank for purified water; 7 - second pumping station.

In addition to chloroform during the test period in the analyzed water after each purification stage, bromodichloromethane was found in the concentrations not exceeding $10 \mu \mathrm{g} / \mathrm{l}$. The other volatile halogenated hydrocarbons were absented in the water. With increasing of the temperature of the river water in the summer and bacterial contamination of the water source, it can be assumed that the concentration of chloroform in purified water using chlorine will be much higher. There will be to an increase in the risk of disease of the population from the consumption of the low-quality water. 


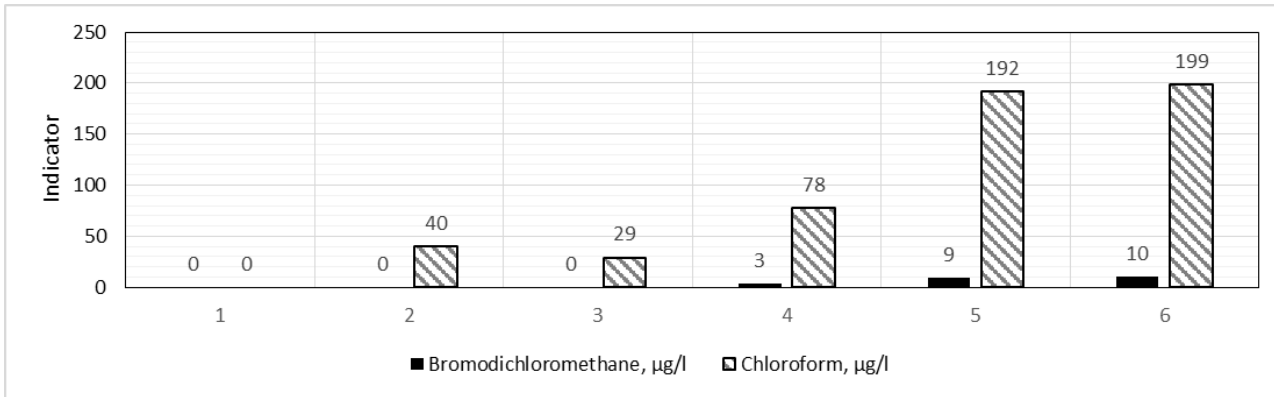

Fig. 2. Dynamics of change of trihalomethanes in the process of water purification at the waterworks № 21 - source water; 2 - after prechlorination; 3 - clarifier with a layer of suspended sediment; 4 filter; 5 - tank for purified water; 6 - second pumping station.

\section{Conclusions}

The dynamics of formation and changes in the concentration of THM in the process of the water treatment in comparison with the quality and treatment modes of the river water was studied at two stations with different technologies.

It is illustrated that the standards for the drinking water are carried out for all indicators except THMs.

It is established that the traditional water supply facilities do not perform a barrier function in the relation to the flow of chloroform into the drinking water. In the drinking water, the concentration of chloroform exceeds the maximum allowable in 3,3-3.5 times and the development of improved technology aimed at ensuring the standards of THMs in drinking water requires.

\section{References}

1. M.J. Rodríguez, G. Rodríguez, J. Serodes, R. Sadiq, Interciencia, 32/11, 749-756 (2007)

2. B. Tokmak, G. Cpar, F.B. Dilek, U. Yetis, J. Envir. Research, 96/11, 345-352 (2004)

3. E.D. Prokopov, G.V. Maktaz, J. of Water Chem. and Technol.(Khim. i tekhnol. vody), 15/9, 633-640 (1993)

4. L.P. Alekseyeva, Vodosn. i san. tekhnika, 9, 27-34 (2009)

5. A. Domínguez Tello, T. García-Barrera, A. Arias Borrego, J.L. Gómez Arisa, Cong. Nac. del medio ambiente (2012). Available at: https://www.researchgate.net/publication/318987317/download

6. I.Y. Arutyunova, O.B. Kalashnikova, Vodosn. i san. tekhnika, 10, 18-22 (2012)

7. R.W. Brett, J.W. Ridgeway, J. IWES, 5/2, 23-32 (1981)

8. P.C. Singer, J. of Environ. Eng., 120/4, 727-744 (1994)

9. J. García-Villanova, C. García, J.A. Gomea, M.P. García, R. Ardanuy, J. Water Research, 31/6, 1405-1413 (1997)

10. A.A. Stevens, L.A. Moore, R.J. Miltner, J. AWWA, 81/8, 54 (1989)

11. M. de la Cruz Vera, L. Soler Nieto, J.L. Criado González, M.P. Llavero del Pozo, J.I. Vílchez Zamorro, J.M. Palero Sanz, Tecnoaqua, 2, 42-50 (2013)

12. S. Arjona, P. Torres, C. Cruz, D. Loaiza, J. Escobar, Rev. Ing. Un. de Medellín, 11/20, 57-65 (2012) 
13. A.G. Vitenberg, Y.G Dobryakov, L.A. Konopel'ko, I.B. Maksakova, J. Anal. Chem., 66/8, 745-755 (2011)

14. SanPiN (Sanitary Rules and Regulations) 2.1.4.1074-01. Pit'evaja voda. Gigienicheskie trebovanija $k$ kachestvu vody centralizovannyh sistem pit'evogo vodosnabzhenija. Kontrol' kachestva. Sanitarnyepravila i normy (Tehnormativ, 2010) 